Kerala is one of the biodiversity rich states of India that is well known for its wetlands with a total area of 160,590ha (National Wetland Atlas: Kerala 2010). Wetlands are important as it improves water OPEN ACCESS quality, reduce flood damage, reduce erosion and as an ecosystem that provide food, shelter, breeding and resting places for an incredible

number of species of plants, mammals, birds, reptiles, amphibians, fish and other invertebrates. Wetlands provide the critical habitat for many such organisms to survive (Buckton 2007). Wetlands also support livelihood of the people around it.

Vellayani-Punjakari wetlands are home to many resident birds and a major landing site for several migratory birds. Vellayani Lake is one of the most important fresh water lakes of the capital city of Kerala, Thiruvananthapuram. It is one of the three rain-fed freshwater lakes of Kerala. The lake is aligned in northsouth direction and lies between $8^{\circ} 24^{\prime} 09^{\prime \prime}-8^{\circ} 26^{\prime} 30^{\prime \prime} \mathrm{N}$ \& $76^{\circ} 59^{\prime} 08^{\prime \prime}-76^{\circ} 59^{\prime} 47^{\prime \prime} E$. Vellayani-Punjakari wetland is also a rich repository of flora and fauna and is renowned for its bird diversity.

Birds have become of interest as indicators of wetland quality and as parameters of restoration success and regional biodiversity. Kerala is a bird paradise and to date a total of 500 species of birds have been documented within its boundary (Praveen 2015). Vellayani has been a hotspot for birding, for it has an abundant diversity of water birds. The lake with its lush green surroundings is also home to many species of birds other than wetland birds. Several species of

\section{Sighting Of Red-BREASted PARAKEet PSITTACULA ALEXANDRI (LINNAEUS, 1758) (PSITTACIFORMES: PSITTACULIDAE) FROM Vellayani, ThiRUVANANTHAPURAM, Kerala, INDIA}

\author{
Linda John ${ }^{1}$, Sujith V. Gopalan ${ }^{2}$, S. Priyanka ${ }^{3}$ \& \\ Krishna Panicker Laladhas ${ }^{4}$ \\ ${ }_{1,2,3,4}$ Kerala State Biodiversity Board, L-14, Jai Nagar, Medical College
P.O., Thiruvananthapuram, Kerala 695011, India
${ }^{1}$ lindaraajan@gmail.com, ${ }^{2}$ sujith.vg@gmail.com, ${ }^{3}$ pinkey.jayaraj@
gmail.com, ${ }^{4}$ laladhas@gmail.com (corresponding author)
}

migratory birds have been documented over the years from Vellayani Lake and the surrounding area.

There are 391 species of parrots recorded worldwide, of which 12 species are found within India (Praveen et al. 2014). Kerala is home to five species of parakeets namely, Alexandrine Parakeet Psittacula eupatria, Rose-ringed Parakeet Psittacula krameri, Plum-headed Parakeet Psittacula cyanocephala, Blue-winged Parakeet Psittacula columboides and Vernal Hanging-parrot Loriculus vernalis.

Red-breasted Parakeet or Moustached Parakeet Psittacula alexandri is among the most widespread species of the genus (del Hoyo et al. 1997) and is known for most of its geographical variations. Most of the variants of the species are limited to small islands. The variation has been documented in sub-species level and one among them occurs in Andaman Islands with its partial range along the foothills of the Himalaya and northeastern India. Psittacula alexandri is classified as near threatened (NT) species by IUCN.

Red-breasted Parakeet is easily identified from its

DOI: http://dx.doi.org/10.11609/jott.2201.8.4.8732-8735

Editor: P.O. Nameer, Kerala Agricultural University, Thrissur, India.

Date of publication: 26 April 2016 (online \& print)

Manuscript details: Ms \# 2201 | Received 11 August 2015 | Final received 18 March 2016 | Finally accepted 20 March 2016

Citation: John, L., S.V. Gopalan, S. Priyanka \& K.P. Laladhas (2016). Sighting of Red-breasted Parakeet Psittacula alexandri (Linnaeus, 1758) (Psittaciformes: Psittaculidae) from Vellayani, Thiruvananthapuram, Kerala, India. Journal of Threatened Taxa 8(4): 8732-8735; http://dx.doi.org/10.11609/jott.2201.8.4.8732-8735

Copyright: @ John et al. 2016. Creative Commons Attribution 4.0 International License. JoTT allows unrestricted use of this article in any medium, reproduction and distribution by providing adequate credit to the authors and the source of publication.

Funding: Kerala State Biodiversity Board.

Conflict of Interest: The authors declare no competing interests.

Acknowledgements: Authors are thankful to government of Kerala for financial assistance. 


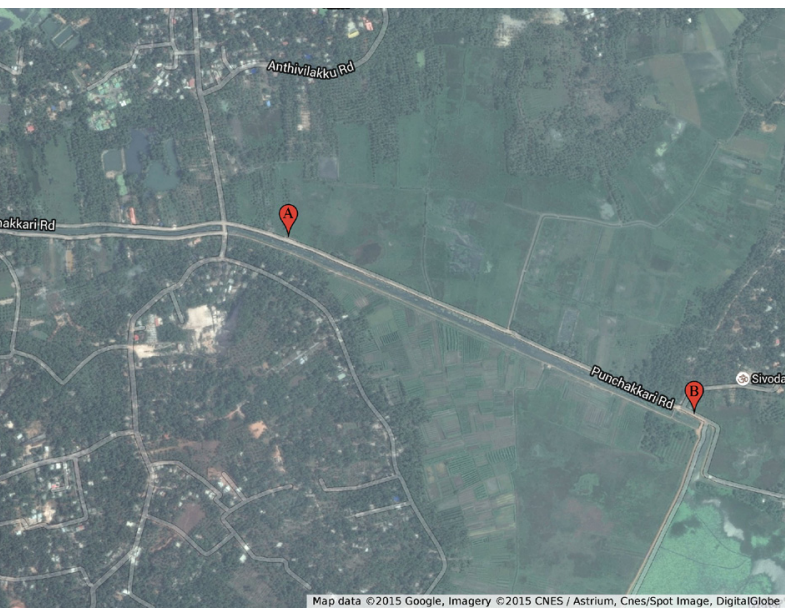

Image 1. Study area - Puncakari-Vellayani wetland

congeners by its "moustache" like black stripe below its beak that gives the name Mustached Parakeet. The other dominant feature of the species being uniform grey-blue head, narrow line from forehead to eye, breast and upper abdomen salmon pink, upper side of middle tail-feature blue with green yellow tips and outer tail feather blue-green.

Materials and Methods: The study is in progress since 06 November 2014. The aim of the survey was to survey a $1 \mathrm{~km}$ line transect twice every week, in order to gather a run of comparable data and ideally surveyed by the same person over the year. Sampling was targeted to record the species diversity, number of individuals of each species and nesting (Buckland et al. 2001; Gibbons \& Gregory 2006). A $1 \mathrm{~km}$ transect was identified through the core area of PuncakariVellayani wetland (Image 1). Surveys were carried out in the early morning (06:00-07:30 hr) to coincide with maximum bird activity. The average time for the survey visit was around 90 minutes. For better spotting of birds an Olympus DPS I 10×50 binocular was used. The identification of birds was confirmed following the field guide of Grimmett et al. (1998).

Result: The survey of Vellayani-Punjakari wetlands revealed an amazing diversity of birds including the sighting of Red-breasted Parakeet. To date, the study has recorded 129 species of birds. On 18 April 2015 two birds were sighted on a coconut palm standing along the side of the road, running parallel to the canal which was along the $1 \mathrm{~km}$ transect route. The two birds were later identified as males from photographs (Image 2). The two parakeets came to be noticed by the distress calls made by them that were significantly different from the familiar calls of Rose-ringed Parakeet of Vellayani. The
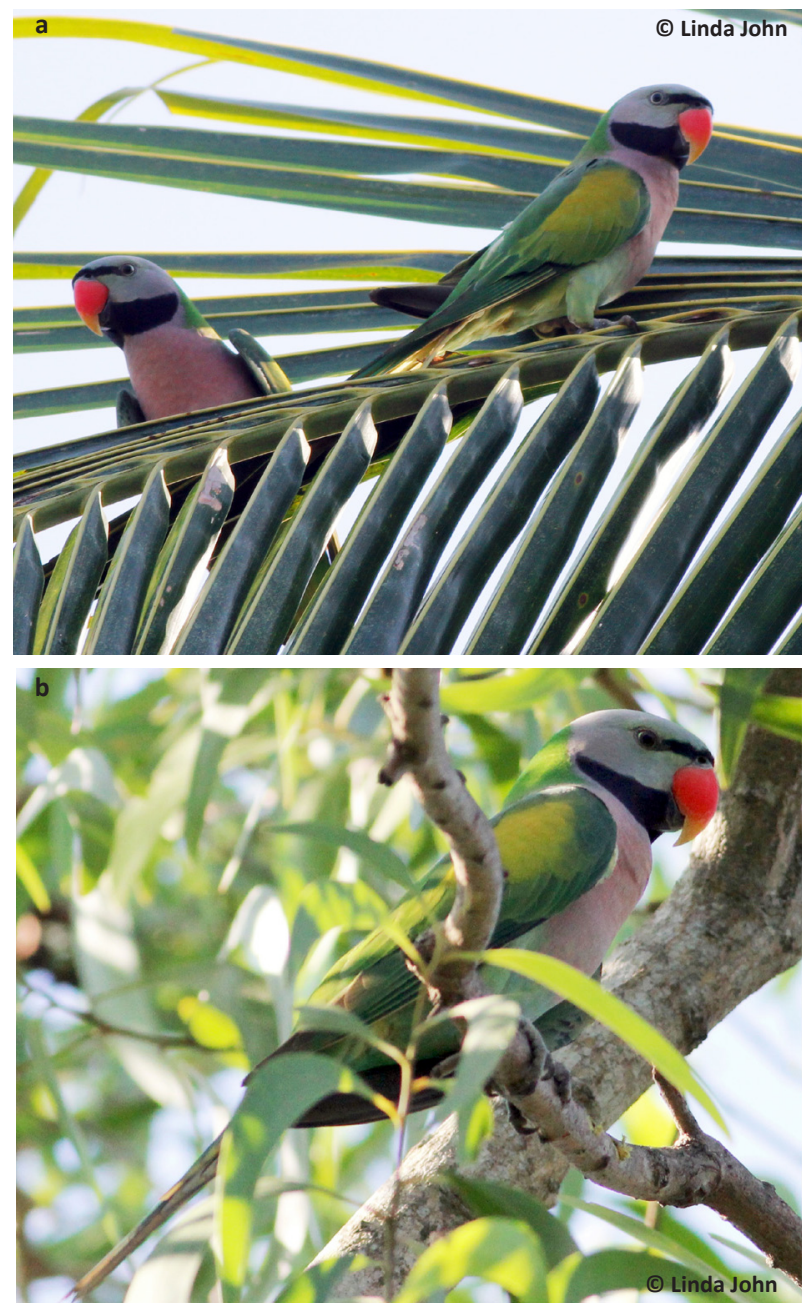

Image 2. Red-breasted Parakeet Psittacula alexandri

birds were unfamiliar to the resident birds which was evident from the behavior of crows chasing them.

Discussion: Across invader taxa, ecosystem types and geographic locations, invasive species are capable of altering ecosystem services by affecting populations, community interactions, ecosystem processes, and abiotic variables.

The biodiversity of India is threatened by numerous factors and the last decade has seen serious threat to diversity from invasive species. African Catfish Clarias gariepinus, Red-bellied Piranha Pygocentrus nattereri and South American Suckermouth Armoured Catfish (Pterygoplichthys spp.) have invaded our fresh water ecosystem and depleted populations of our endemic fish species pushing them to extinction (Krishnakumar et al. 2011; Singh et al. 2014). Lantana camara, Wedelia trilobata, Mimosa diplotricha and other floral invasive species have replaced many native species in 
wild (Raghubanshi et al 2005). African Snail Achatina fulica has colonized and established well throughout Kerala and is already a serious pest (Mathai 2014). Western Ghats is known as an amphibian hot spot. For the first time in 2011 "killer fungus" Batrachochytrium dendrobatidis which causes Chytridiomycosis in amphibians was reported from Western Ghats (Nair et al. 2011), further its widespread occurrence in Western Ghats was reported in 2013 and 2015 (Dahanukar et al. 2013; Molur et al. 2015). Amphibian trade and introductions are prominent hypotheses for the spread of $B$. dendrobatidis in many parts of the world (Fisher \& Garner 2007).

Birds have been introduced beyond their native range for diverse reasons such as aesthetics, food, hunting, biological control, and the pet trade (Long 1981; Duncan et al. 2003). Such introductions by human beings have often led to the successful establishment of many exotic birds and expansion of range beyond native area (Long 1981; Temple 1992). One among such established birds that have been introduced across the world as cage birds is parrots. Today many exotic parrots have established in new areas outside their native range (Blackburn \& Duncan 2001).

Parrots, in general, are known to cause damage to crops in their native range (Long 1981; Jepson et al. 2001 ), especially when they feed on young fruits (Leven \& Corlett 2004). Red-breasted Parakeet in huge flocks are known to raid maize and rice fields in their native range (Long 1981), and have been known to damage up to $50 \%$ of the crops (Jepson et al. 2001). Invasive birds may pose a threat to native bird species through competition for similar resources (Yap \& Sodhi 2004; Peh 2010). On the same food source, the Red-breasted Parakeet has been recorded to consume the entire unripe fruit while native birds feed upon the seeds of its ripen fruits. Such removal of immature fruits may result in less food being available to the native birds (Neo 2012). Red-breasted Parakeet have been recorded disrupting Oriental Pied Hornbill's nesting attempt (Wee et al. 2008). Hole-nest competition with alien birds and the lack of suitable nesting sites may further reduce breeding success of native hole-nesters such as the woodpeckers, barbets, hornbills and other parakeet species.

The cage escapees of Red-breasted Parakeet have been already reported as feral populations from cities like Mumbai and small numbers have been sighted at Chennai and Bangalore and the current sighting increases their presence further south.

Conclusions: Ecological impacts of alien bird species are poorly studied and undocumented in India and hence it's difficult to attribute the impacts of any one particular alien species. The Red-breasted Parakeet presently shows no evidence of any serious impact on native ecology in India. However, an increased population size of these species may pose problems in the long term through seed predation of native plant species or competition with native birds for similar resources such as food and hole-nests. In this context, it is necessary to address the pet trade and impose serious checks on the import of exotic species. In addition, there is a need of generating public awareness on alien species and their impact on ecology.

\section{Reference}

BirdLife International (2015). Species factsheet: Psittacula alexandri. Downloaded from http://www.birdlife.org on 06 August 2015.

Blackburn, T.M. \& R.P. Duncan (2001). Establishment patterns of exotic birds are constrained by non-random patterns in introduction. Journal of Biogeography 28: 927-939; http://dx.doi.org/10.1046/ j.1365-2699.2001.00597.x

Buckland, S.T., D.R. Anderson, K.P. Burnham, J.L. Laake, D.L. Borchers \& L. Thomas (2001). Introduction to Distance Sampling. Oxford University Press, Oxford, 432pp.

Buckton, S. (2007). Managing wetlands for sustainable livelihoods at Koshi Tappu. Danphe 16(1): 12-13; http://dx.doi. org/10.4324/9781849771894

Dahanukar, N., K. Krutha, M.S. Paingankar, A.D. Padhye, N. Modak \& S. Molur (2013). Endemic Asian chytrid strain infection in threatened and endemic Anurans of the Northern Western Ghats, India. PLOS ONE 8(10): e77528; http://dx.doi.org/10.1371/journal. pone.0077528

del Hoyo, J., A. Elliott \& J. Sargatal (1997). Handbook of the Birds of the World - Vol. 4: Sandgrouse to Cuckoos. Lynx Edicions, Barcelona, Spain. Provide total number of pages

Duncan, R.P., T.M. Blackburn \& D. Sol (2003).The ecology of bird introductions. Annual Review of Ecology, Evolution and Systematics 34: 71-98; http://dx.doi.org/10.1146/annurev. ecolsys.34.011802.132353

Fisher, M.C. \& T.W.J. Garner (2007). The relationship between the emergence of Batrachochytrium dendrobatidis, the international trade in amphibians and introduced amphibian species. Fungal Biology Reviews 21: 2-9; http://dx.doi.org/10.1016/j. fbr.2007.02.002

Gibbons, D.W., \& R.D. Gregory (2006). Birds, pp. 308-350. In: Sutherland, W.J. (ed.). Ecological Census Techniques: A Handbook. $2^{\text {nd }}$ edition. Cambridge University Press, Cambridge, 336pp.

Grimmett, R., C. Inskipp \& T. Inskipp (1998). Birds of the Indian Subcontinent. Oxford University Press, New Delhi, 888pp.

Islam, M.Z. \& A.R. Rahmani (2004). Important Bird Areas in India: Priority Sites for Conservation. Indian Bird Conservation Network, Bombay Natural History Society and BirdLife International (UK), 1,200pp.

Jepson, P., N. Brickle \& Y. Cahyadin (2001). The conservation status of Tanimbar Corella and Blue-streaked Lory on the Tanimbar Islands, Indonesia: results of a rapid contextual survey. Oryx 35: 224-233; http://dx.doi.org/10.1046/j.1365-3008.2001.00179.x

Krishnakumar, K., A. Ali, B. Pereira \& R. Raghavan (2011). Unregulated aquaculture and invasive alien species: a case study of the African Catfish Clarias gariepinus in Vembanad Lake (Ramsar Wetland), Kerala, India. Journal of Threatened Taxa 3(5): 1737-1744; http:// dx.doi.org/10.11609/JoTT.o2378.1737-44

Leven, M.R. \& R.T. Corlett (2004). Invasive birds in Hong Kong, China. Ornithological Science 3: 43-55; http://doi.org/10.2326/osj.3.43 
Long, J.L. (1981). Introduced Birds of the World: The Worldwide History, Distribution and Influence of Birds Introduced to New Environments. Universe Books, New York, 528pp.

Mathai, R.S. (2014). The Snail Spurt- An Issue of Concern. International Research Journal of Environment 3(6): 88-91.

Molur, S., K. Krutha, M.S. Paingankar \& N. Dahanukar (2015). Asian strain of Batrachochytrium dendrobatidis is widespread in the Western Ghats, India. Diseases of Aquatic Organisms 112: 251-255; http://dx.doi.org/10.3354/dao02804

Nair, A., O. Daniel, S.V. Gopalan, S. George, K.S. Kumar, J. Merila \& A.G.F. Teacher (2011). Infectious disease screening of Indirana frogs from the Western Ghats biodiversity hotspot. Herpetological Review 42(4): 554-557.

National Wetland Atlas: Kerala (2010). SAC/RESA/AFEG/NWIA/ ATLAS/14/2010, Space Applications Centre (ISRO), Ahmedabad, India, 130pp.

Neo, M.L. (2012). A review of three alien parrots in Singapore. Nature in Singapore 5: 241-248.

Peh, K.S.H. (2010). Invasive species in Southeast Asia: The knowledge so far. Biodiversity and Conservation 19: 1083-1099; http://dx.doi. org/10.1007/s10531-009-9755-7
Praveen, J., R. Jayapal \& A. Pittie (2014). Notes on Indian rarities - 2: waterfowl, diving waterbirds, and gulls and terns. Indian Birds 9(5\&6): 113-136.

Praveen, J. (2015). A checklist of birds of Kerala, India. .Journal of Threatened Taxa 7(13): 7983-8009; http://dx.doi.org/10.11609/ JoTT.2001.7.13.7983-8009

Raghubanshi, A.S., L.C. Rai, J.P. Gaur \& J.S. Singh (2005). Invasive Alien Species and Biodiversity in India. Current Science 88(4): 539-540.

Singh, A., A. Ansari, S. Srivastava, P. Verma \& A. Pathak (2014). Impacts of Invasive Fishes on Fishery Dynamics of the Yamuna River, India. Agricultural Sciences 5: 813-821; http://dx.doi.org/10.4236/ as.2014.510086

Temple, S.A. (1992). Exotic birds: A growing problem with no easy solution. The Auk 109: 395-397; http://dx.doi.org/10.2307/4088214

Wee, Y.C., K.C. Tsang, M. Chan, Y.M. Chan \& A. Ng (2008). Oriental pied hornbill: Two recent failed nesting attempts on mainland Singapore. Birding ASIA 9: 72-77.

Yap, C.A.M. \& N.S. Sodhi (2004). Southeast Asian invasive birds: Ecology, impact and management. Ornithological Science 3: 57-67; http://doi.org/10.2326/osj.3.57

\section{Erratum}

Stanton, D.J. \& M.R. Leven (2016). Distribution, habitat utilisation and conservation status of the freshwater crab, Somanniathelphusa zanklon Ng \& Dudgeon, 1992 (Crustacea: Brachyura: Gecarcinucidae) endemic to Hong Kong. Journal of Threatened Taxa 8(3): 8564-8574; http://dx.doi.org/10.11609/jott.2070.8.3.8564-8574

Text currently reads on page 8567 under RESULTS: Habitat requirements of S. zanklon:

Somanniathelphusa zanklon was mostly found either in lowland watercourses or wetlands/marsh, with all records below $220 \mathrm{~m}$.

should read: Habitat requirements of S. zanklon:

Somanniathelphusa zanklon was mostly found either in lowland watercourses or wetlands/marsh, with all records below $430 \mathrm{~m}$. 